\title{
Investigation of Copy Number Changes in CYP21A2 Gene By Using MLPA Technique in Patients with Congenital Adrenal Hyperplasia
}

\author{
Konjenital Adrenal Hiperplazi Vakalarında CYP21A2 Geni Kopya Sayısı Değişimlerinin MLPA Tekniği İle
} İncelenmesi

\section{Bakhtiyar Mammadov, (D) Aysel Kalaycı Yiğin, (D) Filiz Özdemir, (D) Ahmet Özaydın, (D) Mehmet Seven} İstanbul Üniversitesi-Cerrahpaşa, Cerrahpaşa Tıp Fakültesi, Tıbbi Genetik Anabilim Dalı, İstanbul.

Congenital adrenal hyperplasia $(C A H)$ belongs to the group of familial diseases with autosomal recessive inheritance, which is caused by a disorder of adrenal steroid production. It is caused by the deficiency of any of the five enzymes that provide cortisol synthesis from cholesterol in the adrenal cortex. Characteristic of $C A H$ is ambiguous genital structure and impaired sexual development. The most common cause of $C A H$ is 21-hydroxylase enzyme deficiency. The CAH, which is caused by 21-hydroxylase deficiency, has 2 types as 'classic' and 'non-classical'. The differences in the clinical picture depend on the structural and functional changes caused by mutations in the 21-hydroxylase gene.

The two steroid 21-hydroxylase genes (CYP21A2 active gene, CYP21P pseudogene) are located on the short arm of chromosome 6. The mutations that cause defect of the active gene are due to the fact that active and pseudogene are very close and quite homologous. Deletions, duplications, gene conversions and point mutations occur as a result of intergenic recombination of the DNA sequence. Due to the presence of CYP21A2 pseudogene; there are often problems in diagnosing CAH, which develops due to 21 -hydroxylase deficiency only with sequence analysis studies for the CYP21A2 gene.

In this study; patients who were directed to Department of Medical Genetics in Cerrahpasa Medical Faculty for CYP21A2 gene mutation analysis were reevaluated with clinical and laboratory findings. It was aimed to determine the number of copy changes that could not be detected in the sequence analysis. Therefore; ensuring the treatment of the patients without delay in their diagnosis; In addition, it is aimed to demonstrate that MLPA method is an easy, relatively cheap, fast and reliable method in mutation analysis for the CYP21A2 gene.

With the MLPA method, 28 patients were included in the study, homozygous deletion covering the majority of the gene in 1 patient, heterozygous deletion in 2 patients and heterozygous duplication in 1 patient were detected.

ÖZET

Konjenital adrenal hiperplazi (KAH), adrenal steroid yapımının bozukluğu ile olușan ve otozomal resesif kalttım gösteren ailesel hastallklar grubundandir. Adrenal kortekste kolesterolden kortizol sentezini sağlayan bes enzimden herhangi birinin eksikliği sonucu olușmaktadır. KAH'in karakteristik özelliği. kuşkulu genital yap ve bozulmuş cinsel gelişimdir. KAH'ın en sık nedeni ise 21-hidroksilaz enzim eksikliğidir. 21-hidroksilaz enzim eksikliğine bağll KAH'ın, 'klasik' ve 'klasik olmayan' olarak 2 tipi vardır. Klinik tablodaki farkllliklar 21-hidroksilaz genindeki mutasyonların olusturduğu yapısal ve fonksiyonel değişikliklere bağlldır.

İki steroid 21-hidroksilaz geni (CYP21A2 aktif gen, CYP21P psödogen) 6. kromozomun kisa kolu üzerinde bulunur. Aktif genin defektine neden olan mutasyonlar aktif gen ile psödogenin birbirine çok yakın ve oldukça homolog olmalarından kaynaklanmaktadır. DNA dizisinin intergenik rekombinasyonları sonucunda delesyonlar, duplikasyonlar, gen konversiyonlart ve nokta mutasyonlar meydana gelir. CYP21A2'nin psödogeninin bulunması nedeniyle 21-hidroksilaz enzim eksikliğine bağlı gelisen KAH'a sadece CYP21A2 genine yönelik dizi analizi çalışmalarıyla doğru tanı konulmasında çoğu kez aksaklıklar yaşanmaktadır.

Çalışmamızda; Cerrahpaşa Tip Fakültesi Tıbbi Genetik Anabilim Dalı'na CYP21A2 geni mutasyon analizi için yönlendirilen hastalar klinik ve laboratuvar bulgulartyla tekrar değerlendirilmeye alındı ve dizi analizinde saptanması mümkün olmayan kopya sayısı değişikliklerinin belirlenmesi hedeflendi. Böylece; hastaların tanısını kesinleștirerek, tedavilerinin gecikmeden yapılmasının sağlanması ile birlikte CYP21A2 genine yönelik yapılan mutasyon analizlerinde MLPA yönteminin kolay, nispeten ucuz, hizlı ve güvenilir bir yöntem olduğunun gösterilmesi amaçlanmıştır.

Calıșmaya dahil ettiğimiz 28 hastada uygulamış olduğumuz MLPA yöntemiyle, 1 hastada genin büyük kisminı kapsayan homozigot, 2 hastada heterozigot delesyon ve 1 hastada ise heterozigot duplikasyon saptanmiştır.
\end{abstract}

Key Words:

Congenital adrenal hyperplasia,

CYP21A2,

CYP21P,

MLPA

Anahtar Kelimeler:

Konjenital adrenal hiperplazi,

CYP21A2,

CYP21P,

MLPA.

\section{Received: 17.02 .2020}

Accepted: 27.02 .2020

Correspondence: Mehmet Seven, İstanbul Üniversitesi-Cerrahpaşa Cerrahpaşa Tıp Fakültesi Tıbbi Genetik Anabilim Dalı, İstanbul, Turkey. Email: mimseven@istanbul.edu.tr Phone: +90 2124143000

Cite this article as: Mammadov B, Kalaycı Yiğin A, Özdemir F, Özaydın A, Seven M. Investigation Of Copy Number Changes in CYP21A2 Gene by Using MLPA Technique in Patients With Congenital Adrenal Hyperplasia. Phnx Med J. 2020;2(1):1-10. 


\section{GíRIS}

Konjenital adrenal hiperplazi (KAH), adrenal steroid yapımının bozukluğu ile oluşan ve otozomal resesif kalıtım gösteren ailevi hastalıklar grubunda yer almaktadır. Adrenal kortekste kolesterolden kortizol sentezini sağlayan beş enzimden herhangi birinin eksikliği sonucu oluşmaktadır (1). İlk kez 1865 yılında dişi cinsiyet gelişim bozukluğu bulunan bir olguda tanımlanmıştır (2). Bu olguların tedavisi, KAH'ın ilk tanımlandığı günden yaklaşık bir asır sonra kortizonun keşfi ile mümkün olmuştur. Buna rağmen normal büyüme ve pubertenin sağlanmasında hala sorunlar bulunmaktadır (3).

Hipofizden salgılanan ACTH, kolesterolün pregnenolona dönüşümünü sağlayarak steroid sentezini uyarır. Hipotalamo-hipofizer-adrenal eksendeki negatif geri bildirim kortizol ile sağlandığından, kortizol sentezinde gerekli olan enzimlerden herhangi birinin etkinliğindeki azalma hipofizden ACTH salgılanmasında artışa sebep olur $(4,5)$. ACTH salgılanmasındaki artış ise adrenal kortekste hiperplaziye ve sonuç olarak da enzim blokundan önceki kortizol ön maddelerinin ve diğer adrenal steroidlerin artışıyla sonuçlanır (4). Enzim eksikliğinin yerine ve derecesine göre klinik bulgular ve biyokimyasal belirteçler değişkenlik göstermektedir. Mineralokortikoidlerin yapımının azaldığı durumlarda tuz kaybı bulguları ortaya çıkarken, androjenlerin aşırı yapıldığ 1 k1z olgularda virilizasyon, eksikliğinde ise erkeklerde yetersiz maskülinizasyon görülür.

Yenidoğan döneminde kuşkulu genital yapının en sık nedenlerinden biri KAH'dir (6-8). Genel olarak KAH'da karakteristik özellik, kuşkulu genital yapı ve bozulmuş cinsel gelişimdir (4). Cinsiyet gelişim bozukluklarının bir kısmı yenidoğanın acil sorunları arasında yer alır. KAH vakalarının çoğu yenidoğan döneminde kuşkulu genital yapı gösterirken bazıları da puberte döneminde tanı alır (9-11). Doğumda genital anomali sıklığı 1/300 kadar olmakla birlikte, gerçek kuşkulu genital yapı sıklığı 1/5000 civarındadır. Erken tanı, sosyal ve psikolojik nedenler dışında tuz kaybıyla seyreden KAH olgularında olduğu gibi yaşam açısından da önemlidir (11).

21-hidroksilaz enzim eksikliği (21-OHE) KAH'ın en sık nedeni olup, \%90-95 oranında görülmektedir (1). Klasik ve klasik olmayan iki klinik şekli mevcuttur. Klasik 21-OHE basit virilizan (BV) ve tuz kaybettiren (TK) olmak üzere iki ayrı alt tipe ayrılır $(1,5,12,13)$. Yenidoğan dönemindeki klasik 21-OHE insidansı 1/10000-1/15000 olup, etnik gruplar arasında farklılıklar gösterir. Klasik olmayan şekli daha yaygındır. Beyaz irkta insidansı 1/1000 olmakla birlikte, Askenazi Yahudilerinde 1/27, İspanyollarda 1/53, Yugoslavlarda 1/63, İtalyanlarda 1/333 oranında görülmektedir (1,4-6). Türkiye'de yapılan çalışmalarda KAH tanılı vakalarda 21-OHE oranı yaklaşık \%80-85 olarak bildirilmiştir (14).

ACTH prekürsörleri olan pro-opiomelanokortin artarak, özellikle genital bölge ve meme uçlarında hiperpigmentasyona yol açar. Adrenal androjen sentezi artışı dişi bebeklerde hafif klitoris büyümesinden bilateral kriptorşidili erkek görünümüne kadar ağır derecede virilizasyona neden olur. Erkeklerde ise penisin iri ve uzun olması dışında dış genital yapı normaldir $(1,4,5,12,13,15)$.

Tuz kaybettiren tip 21-OHE klasik vakaların yaklaşık \%75'ini olușturur ve aldosteron sentezi bozulur. Eksikliğinde böbrek, kolon, deri ve ter bezlerinden sodyum kaybedilir. Aldosteron eksikliği yanında kortizol eksikliğinin de olması bulguların şiddetini arttırmaktadır $(1,5,6,12)$. Klasik olmayan KAH tipinde dış genital yap1 doğumda normaldir. Bazal 17hidroksiprogesteron (17 OHP) düzeyi klasik tipteki kadar yüksek değildir. Daha geç dönemde ise erken kıllanma, hirsutizm, adet düzensizliği gibi aşırı androjen artışı bulguları ile ortaya çıkmaktadır. 21OHE değişik yaş gruplarındaki klinik bulguları Tablo 1 'de özetlenmiştir.

\section{Hidroksilaz Enzim Eksikliğinin Genetiği}

21-OH enziminin geni CYP21A2 ve psödogeni $(C Y P 21 P)$, kromozom $6 \mathrm{p} 21.3$ üzerinde $\mathrm{MHC}$ kompleksi klas 3 içinde yer alır $(4-6,16)$. CYP21A2 ve

Tablo 1: 21 hidroksilaz enzim eksikliğine bağlı yaşla ilişkili bulgular

\begin{tabular}{|l|l|l|}
\hline \multicolumn{1}{|c|}{ YAŞ } & \multicolumn{2}{|c|}{ Dişi } \\
\hline $\mathbf{0 - 1}$ ay & $\begin{array}{l}\text { Kuşkulu genitalya, Erkek fenotip olabilir } \\
\text { \% 75'inde tuz kayb1 }\end{array}$ & $\begin{array}{l}\text { ERKEK } \\
\text { Bazen skrotal hiperpigmentasyon, } \\
\text { \%75'inde tuz kayb1 }\end{array}$ \\
\hline $\mathbf{1}$ ay-2 yaş & Kliteromegali & $\begin{array}{l}\text { Penis büyümesi, Pubik kıllanma, } \\
\text { Büyümede hızlanma, Kas artış1 }\end{array}$ \\
\hline $\mathbf{2 - 1 2}$ yaş & Pubik kıllanma, Büyümede hızlanma & Pubik killanma, Büyümede hızlanma \\
\hline Ergen & Adet düzensizliği, Hirsutizm, Akne & Boy kısalığı \\
\hline Erişkin & Hirsutizm, Oligomenore, İnfertilite & Testis tümörü, Adrenal bez kalıntısı \\
\hline
\end{tabular}


CYP21P genlerinin her ikisi de 10 ekzonlu ve $3.1 \mathrm{~kb}$ büyüklüğünde olup; her iki gen arasındaki en önemli fark CYP21P geninde fonksiyonel okuma çerçevesinin olmayışıdır. $(4,5,13,16)$.

KAH vakalarının \%90'dan fazlası 21-OH enzim eksikliğinden kaynaklanır (1,6-8). Hastalık steroid 21$\mathrm{OH}$ enzimi geni olan CYP21A2'deki mutasyonlar sonucu oluşmaktadır. Mutasyonların \%90'ından fazlası CYP21A2 ile psödogeni olan CYP21P arasındaki intergenik rekombinasyonlar sonucu ortaya çıkmaktadır. Bunların yaklaşık \%20'si ise mayozdaki "unequal crossing over" neticesinde CYP21P'deki delesyonların CYP21'e aktarıldığı "gene conversion" olayı sonucu hastalığa neden olabilmektedir $(17,18)$.

CYP21P'deki mutasyonlar intron 2' deki Adenin ya da Sitozin'den Guanin'e dönüşüm mutasyonu (IVS2$13 \mathrm{~A} / \mathrm{C}>\mathrm{G}$ ), ekzon 3'de bulunan 8 baz delesyonu (G110A8nt) ve 318. kodondaki anlamsız mutasyonunu (Q318X) içermektedir. 21-OHE'ne bağlı gelişen KAH hastalarında ayrıca CYP21P'de saptanmış 7 yanlış anlamlı mutasyon bildirilmiştir (18).

Majör histokompatibilite kompleksi sınıf 3 içinde, serum kompleman sisteminin 4. komponentlerinden $C 4 B$ geni ve $C Y P 21 A 2$ genini içeren büyük delesyonlar klasik 21-OHE hastalarının \%20'sini kapsamaktadır. Homozigot delesyonlar 21-OHE'nin tuz kaybettiren tipinde daha sık görülür. "Unequal Crossing-over" rekombinasyonu sonucunda 30-kb'l1k gen bölgesi içinde duplikasyonlara yol açabilir $(1,13,19)$. Geniş konversiyonlar klasik 21-hidroksilaz enzim eksikliği hastalarının \%10'unu kapsar (18). Konversiyon sonucu psödogenden aktif gene aktarılan mutasyonlar da enzim aktivitesini bozmaktadır. 21-OHE'ne yol açan mutasyonların \%5-10'u psödogen kaynaklı olmayan de novo delesyon ve gen konversiyonları ile genellikle intergenik rekombinasyonlar sonucu ortaya çıkabilmektedir.

\section{GEREÇ VE YÖNTEM}

$\mathrm{Bu}$ çalışmaya; Cerrahpaşa Tıp Fakültesi, Pediatrik Endokrinoloji ile İç Hastalıkları Genel ve Erişkin Endokrinoloji Polikliniklerinden, 21-OHE'ne bağlı gelişen KAH ön tanısı ile Cerrahpaşa Tıp Fakültesi, Trbbi Genetik Anabilim Dalı polikliniğine CYP21A2 genine yönelik dizi analizi için yönlendirilen ve analiz sonucunda mutasyon tespit edilmeyen 28 hasta dâhil edildi. Çalışmaya dahil edilen hastaların yaşları 11 günlük ile 39 yaş aralığındaydı. Hastaların 24'ü dişi, 4'ü erkek olup, 8 hastanın ebeveynleri arasında akraba evliliği mevcuttu.

Hastaların çalışmaya dahil edilme kriterleri; fenotipik olarak dişi olan veya kuşkulu genital yapı bulunan ve kromozom analizi 46,XX genotipine sahip olanlar ile fenotipik olarak erkek, yaşına göre fallusu büyük, skrotumu koyu renkli olan ve erken yaşta kıllanma görülen bireylerden oluşmaktaydı.
Bu çalışmanın etik kurul onamı İstanbul ÜniversitesiCerrahpaşa, Cerrahpaşa Tıp Fakültesi Etik Kurulu'nun 2016 tarih ve 211397 karar numarası ile alınmıştır.

\section{DNA eldesi:}

Hastalardan alınan 2cc periferik kan örneklerinden ticari kit (Roche Diagnostics GmbH, Mannheim, Germany) kullanılarak DNA izolasyonları yapıldı.

DNA Örneklerinin Multipleks Ligasyona Bağımlı Prob Amplifikasyonu (MLPA) Yöntemiyle Analizi:

DNA izolasyonunu takiben, $C Y P 21 A 2, C Y P 21 P, T N X B$ ve genlerine yönelik üretilmiş olan MLPA kiti (SALSA MLPA KIT P050-C1 CAH, Holland) kullanılarak analiz yapıld1. Bu kit $C Y P 21 A 2$ geninde yer alan geniş rekombinasyonları ve sık karşılaşılan belirli mutasyonları tespit etmek üzere tasarlanmıştır. 27 probdan oluşan setin 12'si KAH lokusunu kapsamakta olup; bu problardan 8'i, CYP21A2'ye özgüdür.

Verilerin analizi Coffalyser.Net yazılımı kullanılarak yapıldı. Pik değerlerini belirlemek için kullanılan rölatif pik oranı (RPR) hastalardan elde edilen değerin, kontrollerin ortalama RPR değerine bölünmesi sonucu bulundu. RPR sonuçları 0,7-1,3 arasında ise normal, 0,7'nin altında delesyon, 1,3'ün üstünde ise duplikasyon olarak kabul edildi.

\section{BULGULAR}

\section{Klinik ve laboratuvar bulguları}

Çalışmaya dahil edilen 28 hastanın 2'sinde sadece kuşkulu genital yapı, 1'inde ise kuşkulu genital yapı ile birlikte kusma, kilo kaybı, ishal şikâyeti, erkek hastaların ise 3'ünde yenidoğan döneminde skrotal hiperpigmentasyon mevcuttu. Dişi cinsiyetli hastaların 8'inde adet düzensizliği ile birlikte kıllanma artışı, kilo artışı, hızlı boy uzaması, erken puberte şikâyetlerinden en az biri vardı. Tüm hastaların bazal 17-OHP düzeyleri 3,4 $\mathrm{ng} / \mathrm{ml}$ 'nin (normal düzey $<2 \mathrm{ng} / \mathrm{ml}$ ) üzerindeydi. 13 hastanın başvuru anındaki kemik yaşları ileriydi. Tüm hastalara CYP21A2 geninin ekzon bölgelerine yönelik dizi analizi yapıldı ve bunlardan hiçbirinde mutasyon saptanmadi.

\section{MLPA Analiz sonuçları}

Çalışmaya dâhil edilen 28 hastaya uygulanan MLPA yönteminde, 2 hastaya ait olan tüm problardan elde edilen pikler aynı boyda dağılım göstermekteydi. Bu hastalar referans olarak belirlendi. 22 no'lu referans hastaya ait Coffalyser Prediction görüntüsü Şekil 1 'de gösterilmiştir. MLPA analizinde değişiklik tespit edilen $10,26,12$ ve 24 no'lu hastalara ait analiz sonuçları aşağıda belirtilmiştir.

10 no'lu hastada $C Y P 21 A 2$ geninin 1, 3, 4, 6 ve 7. ekzonlarına ve $C Y P 21 P$ pseudogenine ait 1,3,4,7. ekzonlarına ait probların pik boylarında referans pik boylarına göre $\% 50$ oranında kayıp olduğu ve heterozigot büyük delesyon taşıdığı belirlendi. 


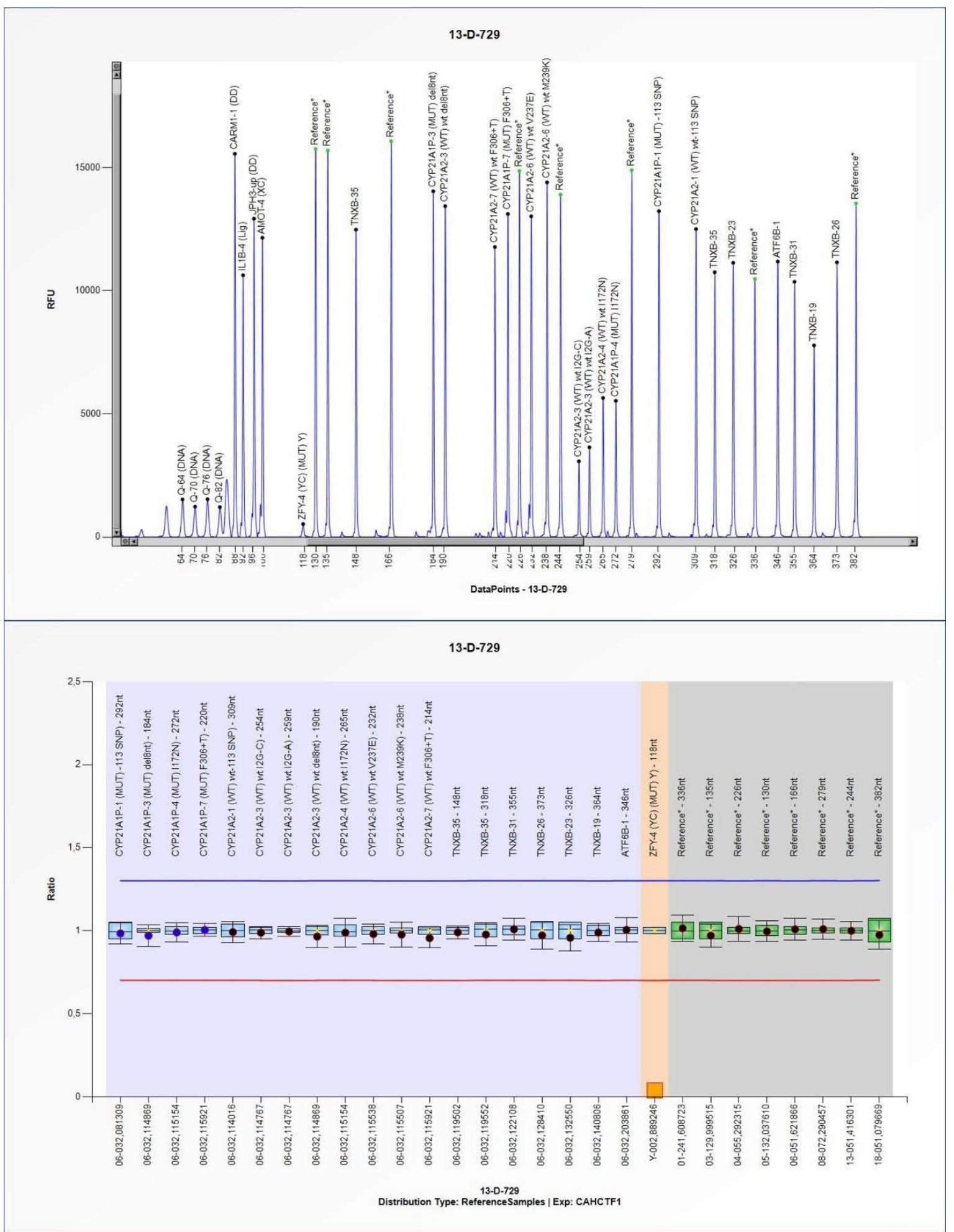

Şekil 1: MLPA analizinde referans olarak belirlenen hastalardan 22 no'lu hastaya ait olan Coffalyser Prediction görüntüsü.

26 no'lu hastada CYP21A2 geninin 4,6 ve 7. ekzonlarına ait pik boylarında referans pik boylarına göre $\% 50$ oranında azalma olduğu, $C Y P 21 P$ pseudogeninin 1 ve 3 . ekzonlarına ait pik boylarında referans pik boylarına göre \%50 oranında artış olduğu ve $C Y P 21 P$ pseudogeninin 4 ve 7 . ekzonlarına ait pik boylarında ise referans pik boylarına göre $\% 100$ oranında artış olduğu tespit edildi (Şekil 2). Bu durum
CYP21A2 geni için heterozigot büyük delesyon, CYP21P'nin ekzon 1 ve 3 . bölgesi için heterozigot duplikasyon, 4 ve 7 . ekzonu için homozigot duplikasyon olarak değerlendirildi.

12 no'lu hastada CYP21A2 geninin $1,3,4,6$ ve 7 . ekzonların pik boylarında referans pik boylarına göre \%50 oranında artış, CYP21P pseudogenine ait 4. ekzonuna özgü tasarlanmış probun pik boyunda 
Phnx Med J. March, Volume 2 No 1

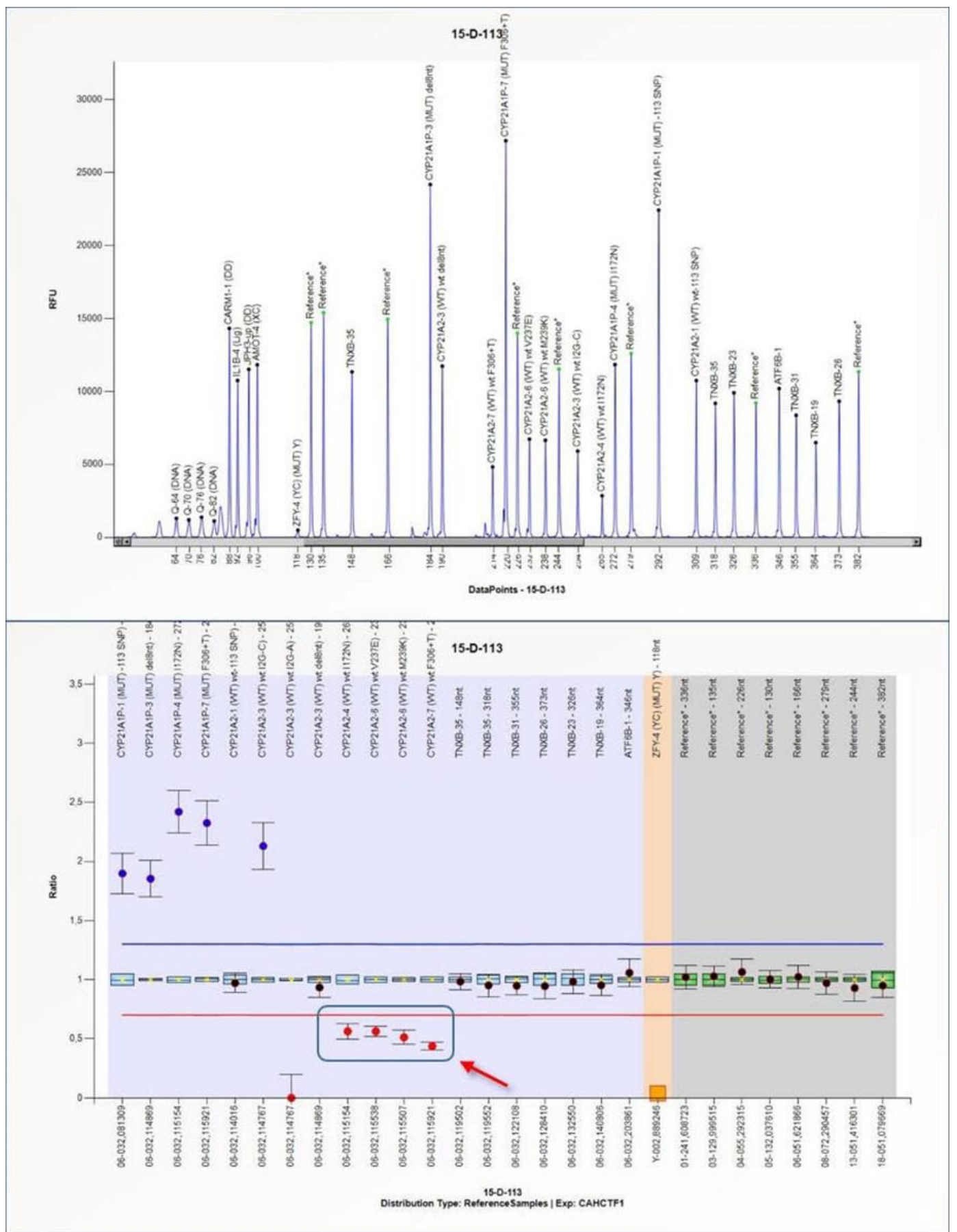

Şekil 2: MLPA analizinde heterozigot delesyon belirlenen 26 no'lu hastaya ait olan Coffalyser Prediction görüntüsü.

referans pik boyuna göre $\% 50$ oranında azalma olduğu görüldü. $\mathrm{Bu}$ hastada $C Y P 21 A 2$ geni için yukarıda belirtilen ekzonlarda heterozigot büyük duplikasyon (Şekil 3), CYP21P geni 4. ekzonunda ise heterozigot büyük delesyon olduğu belirlendi.

24 nolu hastada CYP21A2 geni ekzon 1, 3, 4, 6 ve 7'ye no'lu tasarlanmış probların hiçbirinde pik elde edilemedi. Bu durum homozigot büyük delesyon olarak kabul edildi (Şekil 4). CYP21P'de ise bir değişiklik bulunmad1.

Analiz edilen 8, 16, 20 ve 21 no'lu olgularda ise CYP21P'e özgü ekzon 1, 3, 4 ve 7 için tasarlanmış olan probların piklerinde referans pik boyunun \%50'si oranında azalma olduğu görüldü. Pseudogenlerin kopya sayısında azalma olan bu hastaların heterozigot büyük delesyon taşıdıkları belirlendi. 
Mammadov et al.

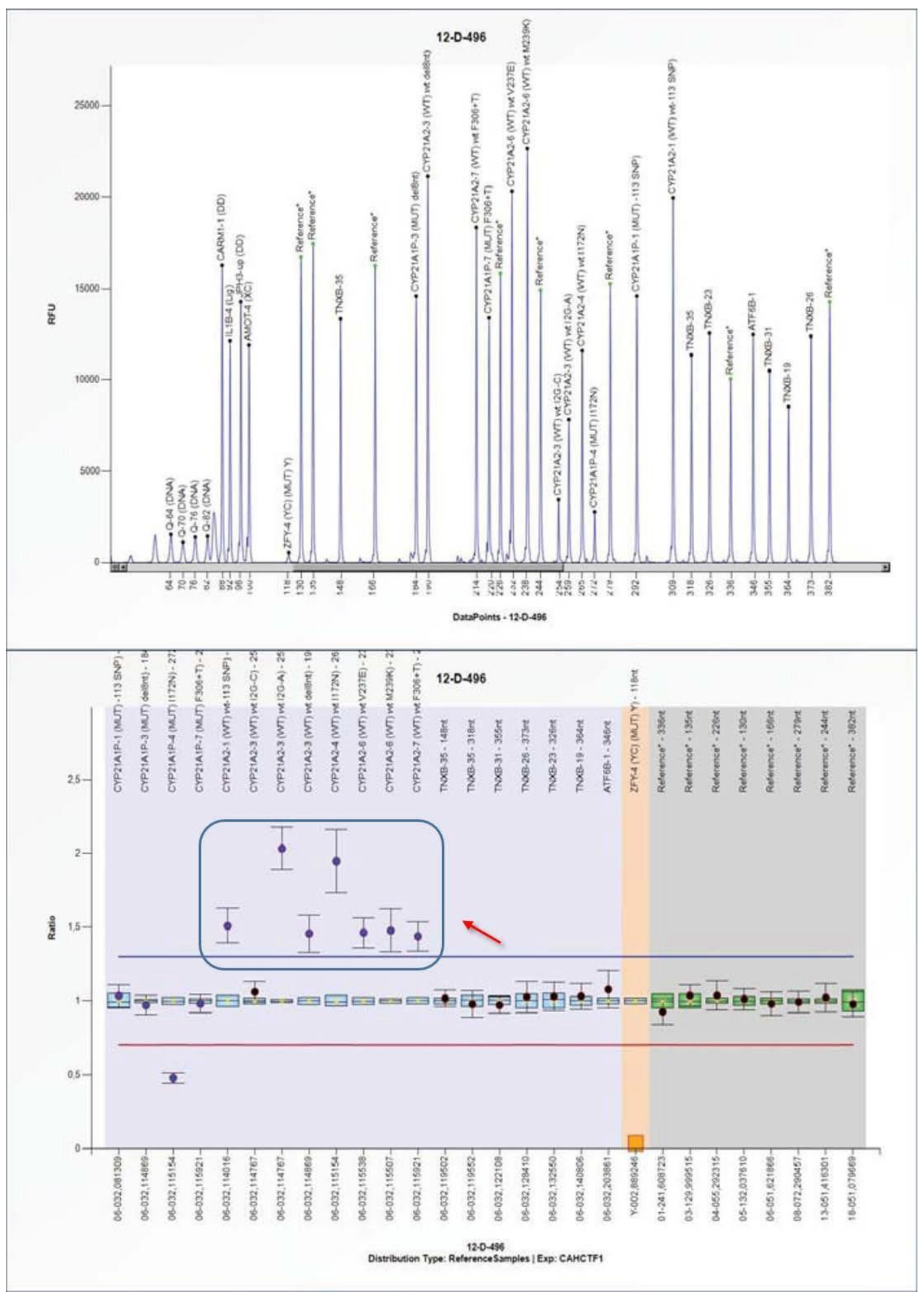

Şekil 3: MLPA analizinde CYP21A2 geninde heterozigot duplikasyon belirlenen 12 no'lu hastaya ait olan Coffalyser Prediction görüntüsü.

3 no'lu vakada $C Y P 21 P$ 'nin ekzon 4 bölgesine özgü pik boyunda referansa göre \%50 oranında artış olduğu ve bu artışın tek ekzon duplikasyonu olduğu belirlendi. 9 no'lu hastada $C Y P 21 P$ geni ekzon 1, 3, 4 ve 7'ye özgü tasarlanmış probların hiçbirinde pik elde edilemedi.
$\mathrm{Bu}$ durum homozigot büyük delesyon olarak kabul edildi. 13 ve 15 no'lu hastalarda $C Y P 21 P$ ekzon $1,3,4$ ve 7 için elde edilen pikler referans pik boyunun \%50'si oranında arttığı belirlendi. $\mathrm{Bu}$ durum CYP21P'nin bu ekzonlarında heterozigot büyük delesyon olarak değerlendirildi. 


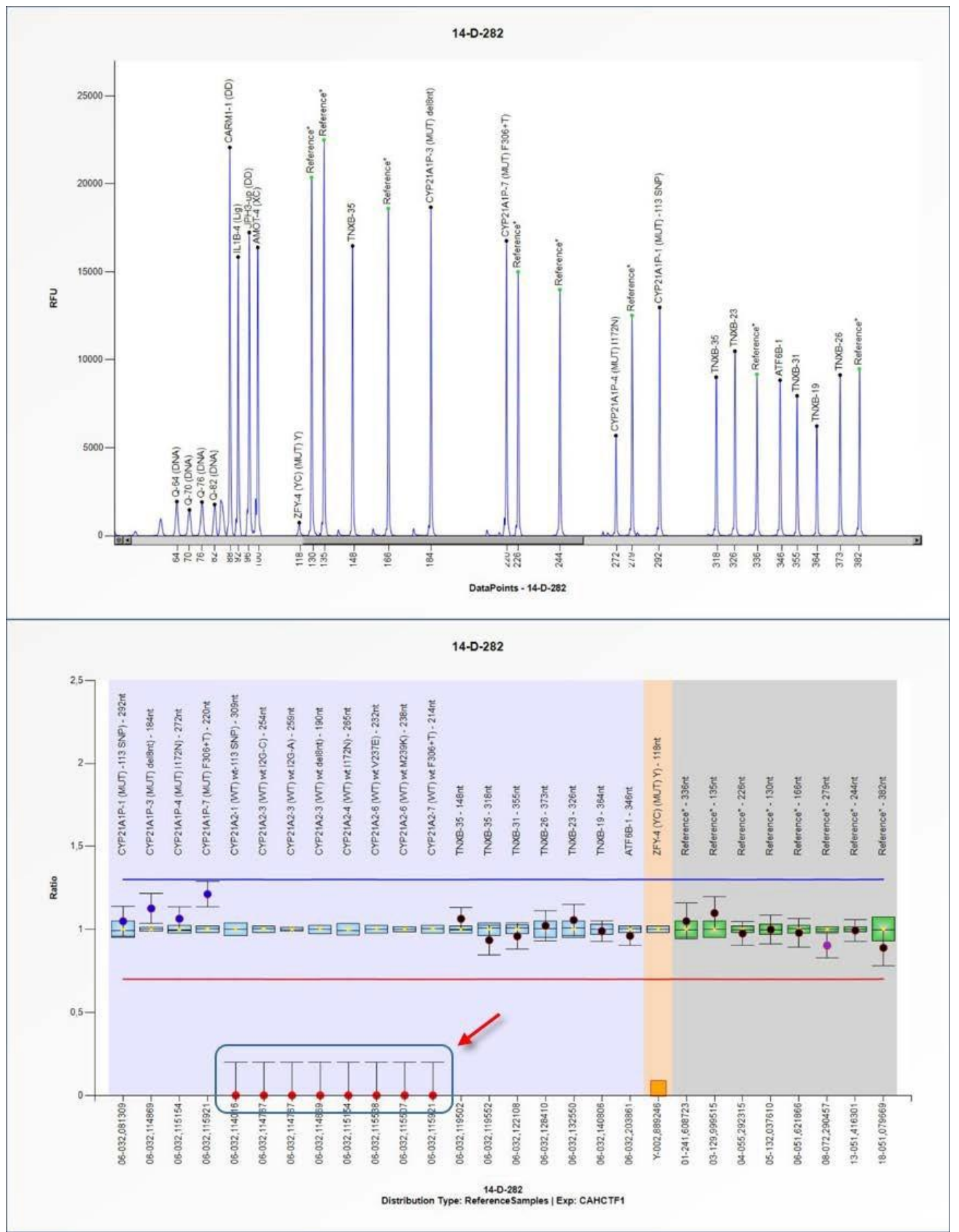

Şekil 4: MLPA analizinde CYP21A2 geninde homozigot delesyon belirlenen 24 no'lu hastaya ait olan Coffalyser Prediction görüntüsü.

\section{TARTIŞMA}

KAH adrenal steroid yapımının bozukluğu ile oluşan ve otozomal resesif kalıtım gösteren genetik bir hastalıktır. Klasik ve klasik olmayan iki klinik şekli mevcut olup Klasik 21-OHE'nin basit virilizan ve tuz kaybettiren olmak üzere iki ayrı alt tipe ayrılır. Yenidoğan döneminde görülen kuşkulu genital yapının en sik sebebi KAH'dır. KAH'a neden olan enzim defekti ise \%90-95 oranında 21-OHE'dir (1,6-8).
21-OHE'ye neden olan 21-OH genindeki mutasyonlar hastalarda yapısal ve fonksiyonel değişiklikler meydana getirir. 21-OHE'ne bağl gelişen KAH steroid 21-OH geni olan CYP21A2'deki mutasyonlar sonucu ortaya çıkmaktadır. Mutasyonların \%90'ından fazlası CYP21A2 geni ile pseudogeni olan CYP21P arasindaki intergenik rekombinasyonlar sonucu oluşmaktadır. Bunların yaklaşı \%20'si ise mayozdaki "unequel crossing over" neticesinde CYP21P'deki delesyonların CYP21A2'ye aktarıldığı "gene conversion" olayının sonucudur $(17,18,20)$. Gen konversiyonları sonucunda 


\section{Mammadov et al.}

da en polimorfik genlerden biri oluşmaktadır. $\mathrm{Bu}$ durum 21-OHE'ne bağlı gelişen $\mathrm{KAH}$ vakalarında genetik etiyolojinin açıklanmasını zorlaştırmakta ve moleküler test sonuçlarının yanlış yorumlanmasına sebebiyet verebilmektedir (21).

Bu çalışmada KAH ön tanısıyla takip edilen $C Y P 21 A 2$ geninde dizi analizi sonucunda mutasyon tespit edilmeyen 28 hastada CYP21A2 geni ve pseudogenindeki kopya sayısı değişiklikleri belirlenerek hastalığın moleküler etiyolojinin aydınlatılması amaçlanmıştır.

21-OHE'ne bağlı klasik KAH'da mutasyon sıklıklarının saptanması için farklı yöntemler kullanılarak pek çok çalışma yapılmıştır. 2005 yılından önce yapılan çalışmalar daha çok dizi analizi ve Southern Blot yönteminin birlikte kullanılmasıyla tek nükleotid değişimleri ve delesyon/duplikasyonları belirlemeye yönelik çalışmalardı. Sonraki yıllarda MLPA yönteminin, kolay uygulanabilir olması, hızlı sonuç alınabilmesi ve güvenilirliğinin artması nedeniyle daha sık kullanılmaya başlanmıştır.

2009 yılında MLPA yöntemiyle yapılan bir çalışmaya, KAH tanisiyla daha önceden dizi analizi ve Southern blot yöntemleriyle mutasyon analizi yapılarak 7'sinde delesyon, 2'inde ise duplikasyon tespit edilmiş olan 18 hasta dahil edilmiş ve aynı sonuçlar elde edilerek MLPA'nın güvenilir ve kolay uygulanabilir bir yöntem olduğu ortaya konulmuştur (22). 2011 yılında yapılan diğer bir çalışmada, dizi analizi ve MLPA yöntemleriyle $C Y P 21 A 2$ genotiplemesi yapılmış ve dizi analizi ile tespit edilemeyen 72 hastanın 23'ünde $(\% 31,9)$ MLPA ile delesyon tespit edilmiştir. Ancak hiçbir hastada duplikasyona rastlanmamıștır (23). 2011 yılında dizi analizi ve MLPA yöntemiyle yapılan başka bir çalışmada ise, 13 klasik ve klasik olmayan $\mathrm{KAH}$ hastasının 5 'inde MLPA yöntemiyle CYP21A2 geninin tek kopyasının bulunduğu belirlenmiştir (21).

$\mathrm{Bu}$ çalışmada yukarıda belirtilen araştırmalarda olduğu gibi CYP21A2 genine yönelik kopya sayıs1 değişiklikleri incelenmiştir. Seçilen hasta popülasyonu, yapılan dizi analizi ile heterozigot veya homozigot nokta mutasyonu tespit edilen olguların dişlandığı, geriye kalan diğer hastaların ise klinik ve laboratuvar bulguları detaylı olarak değerlendirilerek oluşturulan, kriterleri karşılamayanların da çalışma dışında tutulduğu spesifik bir popülasyondan oluşmaktadır. Bununla birlikte; farklı çalışmalarda tespit edilen kopya sayısı değişikliklerinin sıklığ 1 ile tespit ettiğimiz kopya sayısı değişiklikleri oranı birbiri ile benzerlik göstermektedir. Çalıșmaya dahil ettiğimiz 28 hastanın 4'ünde $(\% 14,2) \quad C Y P 21 A 2$ gen kopya sayısında değişiklik gözlenmiş, bu hastaların 1'inde homozigot büyük delesyon, 2 vakada heterozigot büyük delesyon ve 1 olguda ise duplikasyon saptanmıştır.

MLPA yöntemiyle $C Y P 21 A 2$ ve $C Y P 21 P$ gen analizi yaptığımız 10 no'lu hastada $C Y P 21 A 2$ geninin $1,3,4$, 6 ve 7 . ekzonlarına ve $C Y P 21 P$ geninin $1,3,4,7$. ekzonlarına ait probların pik boylarında referans pik boylarına göre $\% 50$ oranında kayıp olduğu ve hastanın heterozigot büyük delesyon taşıdığı belirlendi. Hastanın klinik ve laboratuvar bulgularında adet düzensizliği ve erkek tip kıllanma mevcuttu, 17OHP: $5,01 \mathrm{ng} / \mathrm{ml}$ olup ACTH uyar1 testi sonucu 32,11 ng/ml olarak tespit edildi.

MLPA yöntemiyle $C Y P 21 A 2$ ve $C Y P 21 P$ gen analizi yaptığımız 26 no'lu hastada $C Y P 21 A 2$ geninin 4,6 ve 7. ekzonlarına ait pik boylarında referans pik boylarına göre \%50 oranında azalma olduğu, $C Y P 21 P$ geninin 1 ve 3. ekzonlarına ait pik boylarında referans pik boylarına göre $\% 50$ oranında artış olduğu ve $C Y P 21 P$ geninin 4 ve 7 . ekzonlarına ait pik boylarında ise referans pik boylarına göre \%100 oranında artış olduğu tespit edildi. Bu durum CYP21A2 geni için heterozigot büyük delesyon, $C Y P 21 P$ 'nin ekzon 1 ve 3 . bölgesi için heterozigot duplikasyon, 4 ve 7 . ekzonu için homozigot duplikasyon olarak değerlendirildi. Hastanın klinik ve laboratuvar bulgularında kuşkulu genital yap1 ve 17OHP: $>400 \mathrm{ng} / \mathrm{ml}$ olduğu tespit edildi. $\mathrm{Bu}$ bulgular klasik-virilizan $\mathrm{KAH}$ tanısıyla uyumluydu.

MLPA yöntemiyle $C Y P 21 A 2$ ve $C Y P 21 P$ gen analizi yaptığımız 12 no'lu hastada $C Y P 21 A 2$ geninin $1,3,4$, 6 ve 7 . ekzonların pik boylarında referans pik boylarına göre \%50 oranında artma, CYP21P genine ait 4 . ekzonuna özgü tasarlanmış probun pik boyunda referans pik boyuna göre $\% 50$ oranında azalma olduğu görüldü. $\mathrm{Bu}$ hastada $C Y P 21 A 2$ geni için yukarıda belirtilen ekzonlarda heterozigot büyük duplikasyon, CYP21P geni 4. ekzonunda ise heterozigot büyük delesyon olduğu belirlendi. Hastanın klinik ve laboratuvar bulgularında erkek tipi kıllanma, kilo artışı ve erkek tipi akne mevcuttu. Hastanın 17OHP düzeyi $4,41 \mathrm{ng} / \mathrm{ml}$ olup, ACTH uyarı testi sonucu 29,28 ng/ml olarak tespit edildi.

MLPA yöntemiyle $C Y P 21 A 2$ ve $C Y P 21 P$ gen analizi yaptığımız 24 no'lu hastada $C Y P 21 A 2$ geni ekzon 1,3 , 4, 6 ve 7'ye özgü tasarlanmış probların hiçbirinde pik elde edilemedi. Bu durum homozigot büyük delesyon olarak kabul edildi. Hastanın CYP21A2 genine yönelik yapılan dizi analizlerinde ise iki farklı zamanda alınan periferik kan örneğinden 3 farklı zamanda PZR yapılmış ancak jel elektroforezinde görünür bant elde edilemediği için hastada homozigot büyük delesyon olabileceği düșünüldü ve daha sonra yapılan MLPA analiz sonuçları ile bu düşüncemiz desteklendi. Hastanın klinik ve laboratuvar bulgularında dış genital yap1 fallus görünümündeydi, fallus tabanında tek açıklık mevcuttu, labioskrotal füzyon tamdı ve labioskrotal yapı içerisinde gonad tespit edilmedi. $17 \mathrm{OHP}$ düzeyi $>250 \mathrm{ng} / \mathrm{ml}$, karyotip analizi normaldi. Hastanın klinik ve laboratuvar bulgularıyla düşünülen klasik-virilizan KAH tanısı MLPA sonucu ile doğrulandı.

Çalıșmaya dâhil edilen 28 hastanın 4'ünde CYP21A2 ve $C Y P 21 P$ genlerine ait kopya sayısı değişiklikleri saptand1. Bu hastaların birinde homozigot delesyon tespit edilmesiyle klinik tanı doğrulandı. KAH'ın etiyolojisine çoğunlukla CYP21A2 ve CYP21P 
genlerinde meydana gelen gen konversiyonları sonucu ekzonik bölgelerde oluşan nokta mutasyonları etki etmektedir. Ancak bu bölgeler dişında kalan intronik veya splicing bölgelerinde yer alan mutasyonların da KAH ile ilişkili olduğu bilinmektedir. Dizi analizi ve MLPA çalışmalarında kullanılan primer ve problar sadece kapsadığı bölgenin analizine olanak sağlamaktadır. Bu çalışma sonucunda mutasyon ve delesyon tespit edilmeyen vakalarda $C Y P 21 A 2$ ve CYP21P'e özgü primer ve probların kapsamadığ bölgelerdeki olası değişimlerin kliniğe etki edebileceği, bunun yanısıra bu hastalarda, steroid 21-hidroksilaz aktivitesine sahip P450C21 dişındaki proteinleri kodlayan CYP21A2'den farklı genlerde oluşan değişimlerden kaynaklanmış olabileceği de belirtilmektedir (24). Hastalığın oluşumunda birçok farklı genetik değişimin olduğu göz önünde bulundurulduğunda giderek kullanımı yaygınlaşan, hızlı, kolay ve güvenilir bir değerlendirme yöntemi olan MLPA'nın diğer moleküler genetik tekniklerle birlikte kullanılması halinde hastalığın tanı oranını arttırabileceği düşünülmektedir.

\section{ÇIKAR İLIŞKİsi}

Tüm yazarlar çıkar çatışması olmadığını beyan eder.

TEŞEKKÜR

Bu çalışma İstanbul Üniversitesi Bilimsel Araştırma Projeleri Birimi (BAP) tarafından desteklenmiştir. Proje numarası:

TTU-2016-22410.

\section{KAYNAKLAR}

1. Speiser PW, Azziz R, Baskin LS, Ghizzoni L, Hensle TW, Merke DP, et al. Congenital adrenal hyperplasia due to steroid 21-hydroxylase deficiency: an Endocrine Society clinical practice guideline. J Clin Endocrinol Metab. 2010 Sep;95(9):4133-60.

2. Delle Piane L, Rinaudo PF, Miller WL. 150 years of congenital adrenal hyperplasia: translation and commentary of De Crecchio's classic paper from 1865. Endocrinology. 2015 Apr;156(4):1210-7.

3. Wilkins L, Lewis RA, Klein R, Rosemberg E. The suppression of androgen secretion by cortisone in a case of congenital adrenal hyperplasia. Bull Johns Hopkins Hosp. 1950 Apr;86(4):249-52.

4. New MI. An update of congenital adrenal hyperplasia. Ann NY Acad Sci. 2004 Dec;1038:14-43.

5. New M, Lekarev O, Lin-Su K, Parsa A, Khattab A, Pina C, et al. Congenital Adrenal Hyperplasia. In: De Groot L, Beck-Peccoz P, Chrousos G, Dungan K, Grossman A, Hershman JM, et al., editors. Endotext. South Dartmouth (MA) 2000.

6. Turcu AF, Auchus RJ. Adrenal steroidogenesis and congenital adrenal hyperplasia. Endocrinol Metab Clin North Am. 2015 Jun;44(2):27596.

7. Charmandari E, Brook CG, Hindmarsh PC. Classic congenital adrenal hyperplasia and puberty. Eur J Endocrinol. 2004 Nov;151 Suppl 3:U77-82.

8. Turcu AF, Auchus RJ. Novel treatment strategies in congenital adrenal hyperplasia. Curr Opin Endocrinol Diabetes Obes. 2016 Jun;23(3):225-32.

9. Kim KS, Kim J. Disorders of sex development. Korean J Urol. 2012 Jan;53(1):1-8

10. Hughes IA. Disorders of sex development: a new definition and classification. Best Pract Res Clin Endocrinol Metab. 2008 Feb;22(1):11934.

11. Ahmed SF, Rodie M. Investigation and initial management of ambiguous genitalia. Best Pract Res Clin Endocrinol Metab. 2010 Apr;24(2):197-218

12. Charmandari E, Chrousos G, Merke DP. Classic Congenital Adrenal Hyperplasia. In: Linos D, van Heerden JA, editors. Adrenal Glands: Diagnostic Aspects and Surgical Therapy. Berlin, Heidelberg: Springer Berlin Heidelberg; 2005. p. 101-13.

13. Bas F, Kayserili H, Darendeliler F, Uyguner O, Gunoz H, Yuksel Apak M, et al. CYP21A2 gene mutations in congenital adrenal hyperplasia: genotype-phenotype correlation in Turkish children. J Clin Res Pediatr Endocrinol. 2009;1(3):116-28.

14. Kandemir N, Yordam N. Congenital adrenal hyperplasia in Turkey: a review of 273 patients. Acta Paediatr. 1997 Jan;86(1):22-5.

15. Charmandari E, Brook CG, Hindmarsh PC. Why is management of patients with classical congenital adrenal hyperplasia more difficult at puberty? Arch Dis Child. 2002;86(4):266-9.

16. MD WLMMCEF. Adrenal Cortex and its Disorders. In: Sperling M, editor. Pediatric endocrinology. Fourth edition. ed. Philadelphia, PA: Elsevier/Saunders;2014;p.471,532 pages.

17. White PC, Werkmeister J, New MI, Dupond B. Steroid 21-Hydroxylase deficiency and the majör histocompatibility complex. Hum Immunol. 1986;15(4):404-15.

18. White PC, Speiser PW. Congenital adrenal hyperplasia due to 21-hydroxylase deficiency. Endocr Rev. 2000 Jun;21(3):245-91.

19. Nimkarn S, Gangishetti PK, Yau M, New MI. 21-Hydroxylase-Deficient Congenital Adrenal Hyperplasia. In: Pagon RA, Adam MP, Ardinger $\mathrm{HH}$, Wallace SE, Amemiya A, Bean LH, et al., editors. GeneReviews(R). Seattle (WA)2015.

20. Tsai LP, Lee HH. Analysis of CYP21A1P and the duplicated CYP21A2 genes. Gene. 2012 Sep 10;506(1):261-2.

21. Jang JH1, Jin DK, Kim JH, Tan HK, Kim JW, Lee SY, Ki CS, Park HD. Multiplex ligation-dependent probe amplification assay for diagnosis of congenital adrenal hyperplasia. Ann Clin Lab Sci. 2011;41(1):44-7. 


\section{Mammadov et al.}

22. Concolino P, Mello E, Toscano V, Ameglio F, Zuppi C, Capoluongo E. Multiplex ligation-dependent probe amplification (MLPA) assay for the detection of CYP21A2 gene deletions/duplications in congenital adrenal hyperplasia: first technical report. Clin Chim Acta. 2009 Apr;402(1-2):164-70.

23. Choi JH, Jin HY, Lee BH, Ko JM, Lee JJ, Kim GH, Jung CW, Lee J, Yoo HW. Clinical phenotype and mutation spectrum of the CYP21A2 gene in patients with steroid 21-hydroxylase deficiency. Exp Clin Endocrinol Diabetes. 2012 Jan;120(1):23-7.

24. Miller, W. L. Phenotypic heterogeneity associated with the splicing mutation in congenital adrenal hyperplasia due to 21-hydroxylase deficiency. J Clin Endocrinol Metab. 1997 Apr;82(4):1304. 